\title{
Preparing Graduate Students for Industry and Life Long Learning: A Project Based Approach
}

\section{Preparando estudantes da Pós-Graduação para a indústria e aprendizado para a vida: uma abordagem baseada em projeto}

\begin{abstract}
The case is made that by undertaking projects that have a real-world dimension the students are more likely to gain the skills and abilities which industry requires. Background information is presented relating to links between academia and industry and the role of student projects. Details are given of taught masters level computing programmes at the University of Sunderland and the project that each involves. A particular approach that has enabled hundreds of successful projects to be undertaken with industry ever year is then described along with an assessment of its effectiveness in giving students life-time skills. Keywords: Computing. Projects. Higher Education. Industry. Empowering.

Resumo: Este estudo de caso baseia-se em projetos que têm uma dimensão de mundo real, em que os alunos estão mais propensos a adquirir as competências e habilidades que a indústria exige. Informações de base são apresentadas, relacionando vínculos entre a academia, a indústria e o papel dos projetos dos estudantes. Os dados são provenientes de programas de computação em nível de mestrado, da Universidade de Sunderland, e dos projetos desenvolvidos por cada um dos estudantes. Uma abordagem específica permitiu que centenas de projetos bem sucedidos, realizados anualmente com o setor da indústria, fossem descritos juntamente com a avaliação de sua eficácia em dar aos alunos uma formação de competência para a vida. Palavras-chave: Informática, Projetos, Educação Superior, Indústria, Empoderamento.
\end{abstract}

\author{
J. Barrie Thompson \\ University of Sunderland St. Peter's Way \\ Helen M. Edwards \\ University of Sunderland St. Peter's Way
}

\section{I ntroduction}

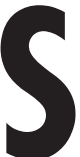

ince the first World Conference on Computers in Education in 1970 there have been significant changes. The capabilities of the Information and Communication Technologies have increased enormously. The provision of university computing programmes has increased not only with regard to the number of programmes and student numbers on them, but also in scope - covering an ever widening spectrum of specialisms. Also, the demands of industry for highly competent graduates who can operate effectively has grown and grown. However, there has been a far from perfect convergence and many industrialists perceive a gap between their needs and what new graduates can offer. The graduate knowledge, skills and abilities that employers' rate highly ${ }^{1}$ are often more related to people skills rather than pure technical ones. Also, it is clear that more needs to done to foster more productive industry and university collaborations as was

1 NATIONAL ASSOCIATION OF COLLEGES AND EMPLOYERS. J ob Outlook 2003. Available from: <http:// www. naceweb.org/> 
made clear during an IFIP Focus Group which considered the subject in $2004^{2}$.

One of the most effective mechanisms to bring universities and industry together and also ensure that graduates have the appropriate skills and abilities is for students to undertake projects that have a real world dimension. Clearly the ideal situation is where students can undertake projects that are directly linked to industry and the importance of this type of activity is emphasised in international curricula documents (e.g. Software Engineering 2004³). However, there are significant challenges to be addressed particularly with regard to ensuring that such projects are academically appropriate with regard to level, satisfy real industry needs (rather than artificial ones), are achievable by the students within programme timetables, and most importantly that sufficient projects of this nature can be found to satisfy the number of students.

The following sections of this paper are organized as follows: sections two and three provide information on our investigations regarding the links between industry and academia and on the role of student projects. In section four we outline the range of taught masters level programmes at the University of Sunderland and give details of the project that each student must undertake as the final part of their programme. Section five provides details of a particular approach which we have developed over the last few years, successfully ensuring that many hundred students each year complete a suitable externally sponsored project - the majority with industry. Finally some reflections are presented.

\section{Motivation Regarding I ndustry and Academic Links}

Both authors of this paper spent a significant

2 IFIP - Report on the Real Life Focus Group that Considered the Experiences and Challenges in Fostering Industry and University Collaborations. In: IFIP Working Conference on Information and Communication Technologies and Real-Life Learning, 2004, Melbourne. Proceedings... New York: Springer, 2005. P. 263-268.

3 SOFTWARE Engineering 2004 - SE2004: Curriculum Guidelines for Undergraduate degree Programs in Software Engineering. - Covington, Kentucky, USA: ACM, IEEE-CS, 2004. Available from: <http:// www.acm.org/education/> time in industry prior to joining the then, Sunderland Polytechnic and close research links were maintained throughout the 1980s and 1990s with external organisations such as the UK government's Central Computer and Telecommunications Agency. We have always believed in the importance of preparing our graduates for effective roles in industry and that they should be equipped with a broad range of technical and non technical skills relevant to being a true professional.

In autumn 2000, to support this wider view and determine trends in the industry we commenced a series of industry orientated investigative activities. These were undertaken primarily within the Software Engineering community and were concerned with both publicising and evaluating a document produced by the International Federation for Information Processing. This provided a framework for professionalism that consisted of six elements: Ethics of professional practice, Established body of knowledge, Education and training, Professional experience, Best practice and proven methodologies, and Maintenance of competence. The work confirmed the value of the overall framework but revealed that there were real concerns regarding the maturity of the areas of best practice and proven methodologies, maintenance of competence, and the educational support for these areas ${ }^{4}$.

Subsequently some further work was undertaken in 2004 investigating the area of best practices ${ }^{5}$ which did much to reinforce the earlier findings. At this time, as will be discussed in section five of this paper, we took on specific academic roles associated with Masters level projects at our university. We envisaged that this would be a means to reinvigorate our research links with industry and provide information on current industrial practices. Starting in 2005 we commenced a further set of externally funded research activities that concentrated on investigating

4 THOMPSON, J.B. Evaluations of IFIP's Proposed Standards for Professionals. In: IFIP WORLD CONFERENCE ON COMPUTERS IN EDUCATION, 8., 2005, Cape Town. Proceedings... Cape Town: University of Stellenbosch, 2005. [s/p.].

5 THOMPSON, J.B.; FOX, A.J. Best Practice: Is this the Cinderella Area of Software Engineering? In: CONFERENCE ON SOFTWARE ENGINEERING EDUCATION AND TRAINING - CSEE\&T 2005, 18., 2005, Ottawa. Proceedings... Los Alamitos: IEEE-CS Press, 2005. P. 137-144. 
the links between industry and academia. Our intention was to identify those practices that industry had found to be particularly effective. As part of these investigations we have run four international workshops, been involved with industry led activities, and carried out literature based investigations. The international workshops were held at:

1. The 19th Conference on Software Engineering Education \& Training, 2006;

2. The 28th International Conference on Software Engineering, 2006;

3. The IFIP's 2006 Conference on Education for the 21st Century - a constituent conference of IFIP's World Computer Congress 2006;

4. The 14th Asia-Pacific Software Engineering Conference, 2007.

The workshops have exposed the wide range of interactions that exist between industry and academia. However, the workshop discussions made it clear that student projects with industry and internships/placements within industry are viewed as being particularly effective.

\section{Project Literature}

Over the years a number of key papers have been published specifically addressing industry/university collaborations (e.g. ${ }^{6}$ ).

However, to determine trends and current levels of pedagogic support we have been carrying out an on-going survey of the papers published in the proceedings of the Conference on Software Engineering Education and Training (CSEE\&T) from 2000. The reasons for choosing this source for our analysis are twofold. Firstly we believe that Software Engineering, rather than the other computing disciplines which are

6 THOMPSON, J.B.; FOX, A.J. Best Practice: Is this the Cinderella Area of Software Engineering? In: CONFERENCE ON SOFTWARE ENGINEERING EDUCATION AND TRAINING - CSEE\&T 2005, 18., 2005, Ottawa. Proceedings... Los Alamitos: IEEE-CS Press, 2005. P. 137-144.

BECKMAN, K.; KHAJENOORI, S.; COULTER, N.; MEAD, N.R. Collaborations: Closing the Industry-Academia Gap. IEEE Software, Los Alamitos, v. 14, n. 6, p. 4957, nov./dec. 1997. addressed in the current IEEE-CS and ACM series of curricula documents, is the discipline that should be aligned most clearly with the industry. Secondly our own interests and prime areas of research lie within the field of Software Engineering and we have a prime interest in educational developments within this field. We believe that since CSEE\&T is the premier outlet for papers concerned with Software Engineering education the proceedings should give us a representative spread. In addition, at least one of us has attended every one of the conferences since 2000 and we have personal in depth knowledge of them. We have examined each item within each of the proceedings and allocated each to one (and only one) of the following coded categories ( 3 specific and 3 general):

$\mathrm{P}+\mathrm{I}$ : Projects with industry links;

P: Projects without industry links;

LI: Links with industry (non-Projects);

C: Curriculum, Body of Knowledge, Programme/Course Development,

Accreditation;

T\&L: Specific approaches to Teaching and Learning (these can relate to a specific subject e.g. Java Programming or a particular environment e.g. Distance Learning);

P\&R: Software Engineering philosophy, Professionalism aspects (including ethics and legal issues), Reviews (e. g. reviews covering past, present and future, global trends etc),

Our approach in undertaking this investigation was to first carry out a rough analysis (giving us an initial list) and then refine this by undertake a more detailed analysis. As stated above each item in the proceedings was counted once only and decisions had to be made regarding what was the most appropriate category. Each item was treated as having equal weight whether it was a full paper, keynote summary, workshop overview, position paper, tutorial overview or whatever. We recognise that there are limitations with regard to this analysis and that there are other publications relating to the area. However, we believe that this investigation is sufficient to draw some conclusions regarding areas of educational research and trends.

A summary of the results for nine years 
of proceedings ${ }^{7}$ to 8 (CSEE\&T, 2000 to CSEE\&T, 2008) is given in Table 1 where the columns represent the categories and the rows represent the years of the conference publications.

TABLE 1 - Analysis of CSEE\&T proceedings 2000 to 2008, [8] to [16]

\begin{tabular}{|c|c|c|c|c|c|c|c|c|}
\hline P+I & P & LI & \multicolumn{2}{|c|}{ C } & T\&L & P\&R & Total & $\begin{array}{c}\text { P+I/ } \\
\text { Total }\end{array}$ \\
\hline 2000 & 2 & 0 & 5 & 23 & 24 & 6 & 60 & $3.3 \%$ \\
\hline 2001 & 1 & 2 & 4 & 6 & 15 & 8 & 36 & $2.8 \%$ \\
\hline 2002 & 1 & 3 & 2 & 9 & 17 & 5 & 37 & $2.7 \%$ \\
\hline 2003 & 2 & 6 & 10 & 7 & 12 & 7 & 44 & $4.5 \%$ \\
\hline 2004 & 0 & 4 & 2 & 5 & 16 & 7 & 34 & $0 \%$ \\
\hline 2005 & 0 & 6 & 2 & 4 & 17 & 5 & 34 & $0 \%$ \\
\hline 2006 & 2 & 4 & 4 & 4 & 18 & 7 & 39 & $5.1 \%$ \\
\hline 2007 & 4 & 3 & 6 & 8 & 24 & 2 & 47 & $8.5 \%$ \\
\hline 2008 & 5 & 3 & 1 & 2 & 17 & 8 & 36 & $14 \%$ \\
\hline
\end{tabular}

What is surprising is the relatively low number of papers which directly address industry-related projects. Also, a closer examination indicates that although some approaches are particularly effective with small numbers of students they may not be so effective when the number of students increase, or they may simply prove impractical with large numbers of students due to the staff resource that would be required. Government predictions (e.g. as reported by the UK Council of Professors and Heads of Computing ${ }^{9}$ ) show that the demand for computing professionals will increase in the coming decade. Hence, it is essential that universities develop approaches in their undergraduate and graduate programs that will ensure their students gain appropriate industry skills. Skills which we believe can best

7 CONFERENCE ON SOFTWARE ENGINEERING EDUCATION \& TRAINING (CSEE\&T 2000), 13., 2000, Austin. Proceedings... Los Alamitos: IEEE Computer Society, 2000.

8 CONFERENCE ON SOFTWARE ENGINEERING EDUCATION \& TRAI NI NG (CSEE\&T 2008), 21. 2008, Charleston. Proceedings... Los Alamitos: IEEE Computer Society, 2008.

9 COUNCIL OF PROFESSORS AND HEADS OF COMPUTING. Report on decline in computing graduates. 2008. Available from: <http://www.cphc.ac.uk/> be developed via appropriate industry related projects.

\section{Masters Computing Projects at the University of Sunderland}

The first taught masters programme was introduced at Sunderland in 1989 backed by government funding. This programme was for non-computing graduates and was a part of a country-wide initiative to address a significant skills shortage within the industry. The programme expanded over the years and was joined by several other MSc programmes each addressing a particular part of the sector. By 2004 the university was offering nine taught Masters programmes in computing (on campus) entitled: Computer Based Information Systems, Information Technology Management, Software Engineering, Electronic Commerce Applications, Electronic Commerce, Health Information Management, Intelligent Systems, Network Systems, and MSc Internet Engineering. In addition three were also available off-campus at centres in the UK, Europe, Africa, Asia and the Arabian Gulf.

The structure for each programme is that the first two-thirds comprises taught modules, with the final third consisting of a final individual capstone project (undertaken for a real-world client). The common details of the leaning outcomes, and the assessment regime for the project modules are provided in an Appendix to this paper.

The important practical parameters associated with each project are:

- The project must have an explicit, identified client.

- The project should take approximately 600 working hours to complete.

- The practical aspect of the project must have a clear link with the subject matter of the specific Masters programme being undertaken.

- The practical work must result in a clearly defined product for the client.

- The student must endeavour to ensure that the client carries out a suitable evaluation of the product.

- The project must be individual in nature. If it is part of a larger project each student's contribution must be coherent, 
discrete and well-defined.

- The project must offer sufficient scope for the student to conduct a critical review of current and relevant literature and the review must feed into the practical aspect of the project in some defined manner.

Each project involves the following actors: Student, Client, Project Tutor(s) for the programme, Academic Supervisor, and a Second Marker. Further details on the development of these MSc. programmes, their structure and assessment regimes can be found in a previous paper that addressed the students' learning experiences ${ }^{10}$.

\section{A Scaleable Approach for Graduate Projects}

At the start of the $2003 / 2004$ academic we took on a joint role of projects tutor for on-campus instances of the MSc. Computer Based Information Systems, the MSC. Information Technology Management, and the MSc. Software Engineering. As outlined in section 2, a major motivating factor was that we envisaged that such a role would improve external links with industry and help advance the University's reach-out and research in Software Engineering. The first year proved very much a learning experience. As detailed in our previous paper ${ }^{11}$ there were many major challenges in particular with regard to finding sufficient projects of a suitable nature.

Projects had normally resulted from a number of sources: contacts developed by members of staff, the University's Business Development Unit, the careers service, the various research groups within the institution, and the students themselves. However, by 2003, the majority of our students were no longer from the UK and hence did not have the

10 THOMPSON, J.B.; EDWARDS, H.M.; HARDY, C.J. Providing Masters Level Computing Students With Real-Life Learning Experiences Via Capstone Projects. In: IFIP WORKING CONFERENCE ON INFORMATION AND COMMUNICATION TECHNOLOGIES AND REALLIFE LEARNING, 2004, Melbourne. Proceedings. New York: Springer, 2005. P. 231-242.

11 THOMPSON, J.B.; EDWARDS, H.M. Advancing Industry-Related Elements: The Meat on the Curricula Bones. In: ANNUAL COMPUTER SOFTWARE AND APPLICATIONS CONFERENCE (compsac2008), 32., 2008, Turku. Proceedings. Los Alamitos: IEEE-CS Press, 2008. P. 447-454. same links that could assist them in finding projects local to the University. Students were allowed to take up projects in other parts of the UK (or even back in their home countries) but this in turn raised extra problems with regard to supervision, control, and tracking. We suffered problems with students not only in starting their projects late but also in maintaining progress and completing on time. Nevertheless, it was clear that many of the best projects were those where the students had identified a project with an external client themselves and where there was a large element of self-interest and motivation (e.g. the possibility of subsequent job, or at least a significant entry for their $\mathrm{CV}$ ). It also became clear that many of the projects that the University's Business Development Unit identified were either too large for an individual student or did not involve a significant research element. In addition, we had concerns with some projects that were being undertaken for research groups within the university where an academic was acting as both client and supervisor and in many cases the practical element was being "lost".

The solutions to these problems did not occur instantly, but developed over a period of time. They were simply to:

Empower the students to find their own projects.

Put in place very formal quality control procedures that would assist in identifying and addressing any problems.

\subsection{Empowerment}

It is unrealistic to expect the majority of students to find suitable projects without support: they need guidance and help. Also, it is necessary that they start seeking potential projects long before the start of the actual project phase. Many students, especially those from outside the UK can find it very daunting to be put in the role of an instigator of a new activity. If students do not have existing contacts they are essentially being put in a position of "cold-calling" potential clients with all the challenges that presents. However, with appropriate support they can gain a set of skills that will benefit them when they come to seek actual employment. The approach we developed has involved: 
- Providing formal sessions well before the project phase to introduce the students to all aspects of the projects.

- Ensuring that students have access to previous project reports to help them understand what will be required plus classroom exercises analysing example reports with regard to: research content, proof of success, and structure.

- Making students aware of the wide range of contacts that they probably already have that could lead to a project and helping them to develop strategies to access these.

- $\quad$ Providing sessions run by the university careers service which give guidance on how to approach an external organisation and how to "sell" oneself. And more importantly identifying common pitfalls that should be avoided.

- $\quad$ Providing sessions where the students work in groups to identify areas of interest, brainstorming to identify potential clients, and (if necessary) work on draft letters of introduction.

- $\quad$ Ensuring that there are staff available who can advise students on the suitability of their initial proposals and provide support and guidance in focusing these.

\subsection{Formal Quality Control Procedures}

We have introduced a number of formal quality checkpoints both before and during the project. These are intended to ensure that the projects are well defined, there is a clear documented commitment from the client, and that once the project is underway any problems are quickly identified and appropriate remedial action can be taken. In chronological order the control procedures are:

- Beforetheprojectphasestartsstudents must provide personal information that can be used in judging their appropriateness for a particular project.

- After identifying a potential project a student produces a formal project proposal which is reviewed by the project tutors or other authorised staff to ensure that the project is of an acceptable standard and has a suitable client

- At the start of the project phase each student must produce a formal Terms of Reference which acts as the contract for their project. The student also produces an associated work plan, and it is expected that they maintain records of meetings with both client and supervisor.

- Approximately one-third into the project the first of two formal reviews with the project tutors occurs where progress is judged.

- Approximately two-thirds into the project the second formal progress review with the project tutors takes place.

- A formal deadline is set for submission of the project dissertation, and in advance of this it is expected that the student will have demonstrated the practical product to both the supervisor and second marker (having already delivered it to client and received feedback from them).

\section{Reflections}

Has our approach been a success? Well, certainly the faculty management believe it has as our model has been adopted across the department; not only for computing masters but also those in engineering. We know that more students are engaging and successfully completing in a managed fashion than was previously the case (where different programmes operated in different ways). It is particularly heartening to see that there is repeat "business" from a number of previous clients. We are also seeing a wide range of well-formed industrially-based projects from around the globe. Certainly many of the problems that the overseas students have previously experienced have been minimised, and they appear to be much more confident in bringing forward proposals. We no longer have the situation where at the start of the project stage there is a significant number of students waiting to be "given" a project.

Most importantly we know that we have a mechanism that will not only result in sufficient projects but that we are equipping our students with a set of skills that will prepare them for industry and life long learning. In particular our approach should ensure that they:

- $\quad$ Are self motivated and have confidence in themselves,

- Have confidence to approach potential 
employers,

- Have gained skills in negotiating with a real-world client,

- Have improved communication skills,

- Are able to produce a formal terms of reference (a contract)

- Have planning and scheduling skills,

- $\quad$ Are able to adapt to changed situations and re-plan and re-schedule,

- Are aware of the importance of formal reviews and being prepared for such,

- That they are able to work to deadlines,

- They take responsibility for their actions and errors and can take appropriate remedial action.

- That they learn the importance of self evaluation and reflection,

- $\quad$ That they gain skills in demonstrating practical deliverables,

- $\quad$ They gain skills in defending their work and the decisions they have made.

Finally, our overall observation is that the key issue in achieving successful industrybased projects for a large scale student body is that there is a clear and effective process underpinned by appropriate support mechanisms.

\section{Acknowledgement}

This paper builds on our previous publications concerned with student projects which are included in the reference list below. It also incorporates material from a short experience report presented at the 2009 Conference on Software Engineering Education \& Training.

\section{References}

BECKMAN, K.; KHAJENOORI, S.; COULTER, N.; MEAD, N.R. Collaborations: Closing the Industry-Academia Gap. IEEE Software, Los Alamitos, v. 14, n. 6, p. 49-57, nov./dec. 1997.

CONFERENCE ON SOFTWARE ENGINEERING EDUCATION \& TRAINING (CSEE\&T 2000), 13., 2000, Austin. Proceedings... Los Alamitos: IEEE Computer Society, 2000.

CONFERENCE ON SOFTWARE ENGINEERING EDUCATION \& TRAINING (CSEE\&T 2001), 14., 2001, Charlotte. Proceedings... Los Alamitos: IEEE Computer Society, 2001.

CONFERENCE ON SOFTWARE ENGINEERING EDUCATION \& TRAINING (CSEE\&T 2002), 15., 2002, Covington. Proceedings... Los Alamitos: IEEE Computer Society, 2002.

CONFERENCE ON SOFTWARE ENGINEERING EDUCATION \& TRAINING (CSEE\&T 2003), 16., 2003, Madrid. Proceedings... Los Alamitos: IEEE Computer Society, 2003.

CONFERENCE ON SOFTWARE ENGINEERING EDUCATION \& TRAINING (CSEE\&T 2004), 17., 2004, Norfolk. Proceedings... Los Alamitos: IEEE Computer Society, 2004.

CONFERENCE ON SOFTWARE ENGINEERING EDUCATION \& TRAINING (CSEE\&T 2005), 18., 2005, Ottawa. Proceedings... Los Alamitos: IEEE Computer Society, 2005.

CONFERENCE ON SOFTWARE ENGINEERING EDUCATION \& TRAINING (CSEE\&T 2006), 19., 2006, Turtle Bay. Proceedings... Los Alamitos: IEEE Computer Society , 2006.

CONFERENCE ON SOFTWARE ENGINEERING EDUCATION \& TRAINING (CSEE\&T 2007), 20., 2007, Dublin. Proceedings... Los Alamitos: IEEE Computer Society, 2007. 
COUNCIL OF PROFESSORS AND HEADS OF COMPUTING. Report on decline in computing graduates. 2008. Available from: <http://www.cphc.ac.uk/>

ELLIS, H.J.C.; MORENO, A.; MEAD, N.R.; SEIDMAN, S. Reeducation to Expand the Software Engineering Workforce: Successful Industry/University Collaborations. Pittsburgh, PA: Carnegie Mellon Software Engineering Institute, 2002. (CMU/SEI-2002-SR-001)

IFIP - Report on the Real Life Focus Group that Considered the Experiences and Challenges in Fostering Industry and University Collaborations. In: IFIP Working Conference on Information and Communication Technologies and Real-Life Learning, 2004, Melbourne. Proceedings... New York: Springer, 2005. P. 263-268

NATIONAL ASSOCIATION OF COLLEGES AND EMPLOYERS. Job Outlook 2003. Available from: <http://www. naceweb.org/>

SOFTWARE Engineering 2004 - SE2004: Curriculum Guidelines for Undergraduate degree Programs in Software Engineering. Covington, Kentucky, USA: ACM, IEEE-CS, 2004. Available from: <http://www.acm.org/ education/>

THOMPSON, J.B. Evaluations of IFIP's Proposed Standards for Professionals. In: IFIP WORLD CONFERENCE ON COMPUTERS IN EDUCATION, 8., 2005, Cape Town. Proceedings... Cape Town: University of Stellenbosch, 2005. [s/p.]

THOMPSON, J.B.; EDWARDS, H.M. Advancing Industry-Related Elements: The Meat on the Curricula Bones. In: ANNUAL COMPUTER SOFTWARE AND APPLICATIONS CONFERENCE (compsac2008), 32., 2008, Turku. Proceedings. Los Alamitos: IEEE-CS Press, 2008. P. 447-454.

THOMPSON, J.B.; EDWARDS, H.M.; HARDY, C.J. Providing Masters Level Computing Students With RealLife Learning Experiences Via Capstone Projects. In: IFIP WORKING CONFERENCE ON INFORMATION AND COMMUNICATION TECHNOLOGIES AND REAL-LIFE LEARNING, 2004, Melbourne. Proceedings. New York: Springer, 2005. P. 231-242.

THOMPSON, J.B.; FOX, A.J. Best Practice: Is this the Cinderella Area of Software Engineering? In: CONFERENCE ON SOFTWARE ENGINEERING EDUCATION AND TRAINING - CSEE\&T 2005, 18., 2005, Ottawa. Proceedings... LoS Alamitos: IEEE-CS Press, 2005. P. 137-144. 


\section{Appendix: Details of Masters Level Project Module for the University of Sunderland, UK.}

\section{Learning Outcome}

Upon successful completion of this module, students will have knowledge of: Academic literature appropriate to the area under study.

Critical awareness of current problems and/or new insights in the IT industry.

And the ability to:

1. Effectively scope a project and meet the stated objectives.

2. Critically assimilate and disseminate research relevant to the specific project area.

3. Use effective time management skills to meet the objectives.

4. Present the results of a project both verbally and in a written form.

\section{Assessment}

Projects will be assessed against the five aspects below:

Research. 30\% . The extent to which the methodical and critical investigation of contemporary material has been incorporated into its development. This must be passed in order for the project to be a pass overall

Success. $\mathbf{2 0} \%$. The extent to which the practical deliverable and the written dissertation achieve the objectives stated in the agreed terms of reference.

Dissertation. $\mathbf{2 0} \%$. The quality, clarity and logical progression, of the written dissertation which deals with the conduct and results of the project.

Viva/ Presentation. $\mathbf{2 0 \%}$. The ability of the student to report, to a viva panel, the conduct of the project and his or her command over the subject area

Reviews/ Control. $\mathbf{1 0 \%}$. The ability to plan, monitor and maintain a viable work schedule.

\section{Source:}

University of Sunderland: http://www.cat.sunderland.ac.uk

Accessed J anuary 2008

Recebido em janeiro de 2009

Aprovado para publicação em abril de 2009

\section{J. Barrie Thompson}

Department of Computing, Engineering and Technology, University of Sunderland St. Peter's Way, Sunderland, SR1 3SD, UK - barrie.thompson@sunderland.ac.uk 